\title{
PRAWO CUDZOZIEMCA DO ODWOŁANIA W PROCEDURZE WYDALENIOWEJ W ŚWIETLE KONWENCJI O OCHRONIE PRAW CZLOWIEKA I PODSTAWOWYCH WOLNOŚCI*
}

\section{WPROWADZENIE}

W wypadku podjęcia przez państwo decyzji o wydaleniu cudzoziemcowi powinna przysługiwać możliwość odwołania się od takiej decyzji do właściwej władzy w celu stwierdzenia legalności zastosowanego środka. O konieczności wprowadzenia procedury kontroli $\mathrm{w}$ sprawach $\mathrm{z}$ zakresu wydalania cudzoziemców, która umożliwiałby im odwołanie się do niezależnego organu, właściwego do zbadania legalności wydalenia, dyskutowano już w 1892 r. w Instytucie Prawa Międzynarodowego, podczas prac nad sformułowaniem podstawowych zasad dotyczących wydalania cudzoziemców. Przyjęto wtedy, że „każda wydalona osoba, jeśli uważa się za rdzennego mieszkańca danego kraju lub podtrzymuje, że jej wydalenie jest niezgodne $\mathrm{z}$ prawem lub też $\mathrm{z}$ traktatem międzynarodowym, który zabrania wydalenia lub stanowczo je wyklucza, ma prawo odwołania się do sądu apelacyjnego, orzekającego w pełnej niezależności od władz państwowych. Jednakże wydalenie może zostać tymczasowo wykonane, co nie stoi na przeszkodzie wniesieniu odwołania" ${ }^{1}$

W październiku 1967 r. Komitet Ministrów Rady Europy świadomy problemów, które mogą się pojawić w wyniku współistnienia Konwencji o ochronie praw człowieka i podstawowych wolności ${ }^{2}$ i Międzynarodowego paktu praw obywatelskich i politycznych (MPPOiP), zlecił Komitetowi Ekspertów ds. Praw Człowieka zbadanie tej kwestii. W 1969 r. Komitet Ekspertów przedłożył raport dotyczący różnic pomiędzy prawami zagwarantowanymi przez EKPC

\footnotetext{
* Niniejszy artykuł powstał $\mathrm{w}$ ramach indywidualnego projektu badawczego „Human rights of individuals who are not nationals of the country in which they live and asylum seekers" w Instytucie Praw Człowieka im. Ludwiga Boltzmana w Wiedniu, sfinansowanego przez Stipendienstiftung der Republik Österreich für Doktoranden.

${ }^{1}$ Międzynarodowe zasady $w$ zakresie przyjmowania $i$ wydalania cudzoziemców (Règles internationales sur l'admission et l'expulsion des étrangers/International Rules on the Admission and Expulsion of Aliens) przyjęte przez Instytut Prawa Międzynarodowego w 1892 r., art. 21.

${ }^{2}$ Dz. U. 1993, Nr 61, poz. 284, powszechnie zwana europejską Konwencją praw człowieka (dalej jako: EKPC lub Konwencja).
} 
a przyznanymi przez MPPOiP ${ }^{3}$. W wyniku prac podjętych przez Komitet Ekspertów, mających na celu rozszerzenie katalogu praw już zawartych w EKPC, 22 listopada 1984 r. $^{4}$ został sporządzony Protokół nr 7 do EKPC, który $\mathrm{w}$ art. 1 wprowadził gwarancje proceduralne dotyczące wydalania cudzoziemców. Zgodnie z tym przepisem:

1. Cudzoziemiec przebywający legalnie na terytorium jakiegokolwiek państwa nie może być zeń wydalony, chyba że w wyniku decyzji podjętej zgodnie z ustawą, i powinien mieć możliwość:

a) przedstawienia racji przeciwko wydaleniu;

b) wniesienia środków odwoławczych oraz

c) bycia reprezentowanym dla tych celów przed właściwym organem albo osobą lub osobami wyznaczonymi przez ten organ.

2. Cudzoziemiec może być wydalony, bez uprzedniego skorzystania ze swoich praw wymienionych w ustępie 1a, b i c niniejszego artykułu, jeśli jest to konieczne z uwagi na porządek publiczny lub uzasadnione względami bezpieczeństwa państwowego ${ }^{5}$.

Należy podkreślić, że art. 1 Protokołu nr 7 ma zastosowanie wyłącznie do cudzoziemców przebywających legalnie na terytorium państwa, które ratyfikowało ten Protokół. Jak dotąd Protokół nr 7 został ratyfikowany przez 43 państwa członkowskie Rady Europy. Jego ratyfikacji nie dokonały jeszcze takie kraje, jak: Niemcy, Holandia i Turcja, natomiast Wielka Brytania nawet go nie podpisała. Ponadto niektóre państwa złożyły do niego odpowiednie deklaracje i zastrzeżenia ${ }^{6}$.

Polska ratyfikowała EKPC 19 stycznia 1993 r., a Protokół nr 7 - 4 listopada 2002 r. Miejsce Konwencji i Protokołów dodatkowych w polskim systemie źródeł prawa określa Konstytucja RP z 1997 r. w art. 87: uznaje, że ratyfikowane umowy międzynarodowe są źródłem powszechnie obowiązującego prawa. Oznacza to, że Konwencja jest źródłem prawa, które może być bezpośrednio stosowane. Dodatkową gwarancję realizacji podstawowych praw i wolności jednostki wynikających z Konwencji i Protokołu nr 7 stanowi art. 9 Konstytucji RP, zgodnie z którym Rzeczpospolita Polska przestrzega wiążącego ją prawa międzynarodowego. Przystąpienie Polski do Konwencji wiąże się nie tylko z zaakceptowaniem standardów wyrażonych w jej przepisach. Doniosłość tego aktu prawnego wyraża się także w poddaniu judykatury polskiej kontroli sprawowanej przez Europejski Trybunał Praw Człowieka w Strasburgu, co jest równoznaczne z pośrednim przejęciem dorobku Trybunału w zakresie prawa do skutecznego środka odwoławczego.

${ }^{3}$ MPPOiP w art. 13 przewiduje, że: „Cudzoziemiec przebywający legalnie na terytorium Państwa Strony niniejszego Paktu może być z niego wydalony jedynie w wykonaniu decyzji podjętej zgodnie z ustawą i będzie miał prawo, jeżeli ważne względy bezpieczeństwa państwowego nie przemawiaja przeciw temu, przedłożyć argumenty przeciwko swemu wydaleniu oraz domagać się ponownego zbadania swej sprawy przez właściwe władze albo osobę lub osoby specjalnie przez te władze wyznaczone i być przed nimi w tym celu reprezentowanym", Dz. U. 1977, Nr 38, poz. 167.

${ }^{4}$ Protokół nr 7 wszedł w życie 1 listopada 1988 r.

${ }^{5}$ Dz. U. 2003, Nr 42, poz. 364. Protokół nr 7 wszedł w życie w stosunku do Polski 1 marca 2003 r.

${ }^{6}$ Przykładowo Szwajcaria zaznaczyła, że w sytuacji gdy wydalenie odbywa się w wyniku decyzji podjętej przez Radę Federacyjną zgodnie z art. 70 Konstytucji z takich przyczyn, jak zagrożenie wewnętrznego i zewnętrznego bezpieczeństwa Szwajcarii, osoba, której to wydalenie dotyczy, nie korzysta z praw wymienionych w art. 1 Protokołu nr 7, nawet po wykonaniu decyzji o wydaleniu. 


\section{PRAWO DO WNIESIENIA ŚRODKA ODWOŁAWCZEGO NA PODSTAWIE ART. 1 PROTOKOLU NR 7 DO KONWENCJI O OCHRONIE PRAW CZLOWIEKA I PODSTAWOWYCH WOLNOŚCI}

Komentarz wyjaśniający do Protokołu nr 7 precyzuje, że prawo krajowe powinno określać organ właściwy w sprawach wydalenia cudzoziemców oraz zasady i tryb postępowania w tych sprawach ${ }^{7}$. Jeśli chodzi o samo rozpatrzenie sprawy o wydalenie, to nie musi ono przybierać formy dwuinstancyjnej procedury prowadzonej przed różnymi organami. Istota tej gwarancji, jak wynika z Komentarza wyjaśniającego, zakłada jedynie to, że kompetentny organ rozpatrzy sprawę ponownie w świetle okoliczności powoływanych przez cudzoziemca i przemawiających przeciwko wydaleniu ${ }^{8}$. Cudzoziemiec i jego przedstawiciel nie musza być fizycznie obecni przed organem rozpatrującym odwołanie od decyzji o wydaleniu. Artykuł 1 Protokołu nr 7 do EKPC nie wymaga bowiem prowadzenia ustnego postępowania, co oznacza, że może odbyć się w formie pisemnej ${ }^{9}$.

Nie jest wymagane, aby organem właściwym w sprawach wydalania cudzoziemców był sąd, ponieważ sprawy wydalania cudzoziemców nie są objęte zakresem prawa do rzetelnego procesu sądowego w rozumieniu art. 6 EKPC. W opinii Europejskiej Komisji Praw Człowieka decyzja o wydaleniu nie zawiera w swojej treści rozstrzygnięcia o cywilnych prawach i obowiązkach ani żadnego oskarżenia w sprawie karnej ${ }^{10}$. Przykładem sprawy, w której Trybunał odmówił zastosowania art. 6 ust. $1 \mathrm{w}$ trakcie procedury wydalenia, jest orzeczenie w sprawie Maaouia p. Francji ${ }^{11}$. Skarżący (obywatel Tunezji będący w związku małżeńskim z obywatelką Francji) po odbyciu kary więzienia za rozbój, w sierpniu 1991 r. otrzymał nakaz opuszczenia terytorium Francji. Ponieważ był nieświadomy tej decyzji, skarżący nie wyjechał z Francji, w wyniku czego został skazany na karę roku pozbawienia wolności i otrzymał zakaz przebywania na terytorium tego państwa przez okres dziesięciu lat. Jednakże na skutek odwołań wniesionych przez cudzoziemca decyzje o jego wydaleniu zostały ostatecznie unieważnione przez władze francuskie w styczniu $1998 \mathrm{r}$. W skardze do ETPC podniósł on, że ze względu na zbyt długo trwające postępowanie w sprawie unieważnienia nakazu deportacji zostało naruszone jego prawo do rzetelnego procesu sądowego w rozsądnym terminie. Trybunał uznał, że decyzje dotyczące wjazdu, pobytu i deportacji cudzoziemców nie dotyczą rozstrzygania o prawach i obowiązkach o charakterze cywilnoprawnym skarżącego ani skierowanego przeciw niemu oskarżenia w sprawie karnej w rozumieniu art. 6 ust. 1 Konwencji, w związku z czym art. 6 ust. 1 EKPC nie

\footnotetext{
${ }^{7}$ Explanatory Report on Protocol No. 7 to the Convention for the Protection of Human Rights and Fundamental Freedoms, ETS, No. 117, par. 11.

${ }^{8}$ Explanatory Report on Protocol No. 7 to the Convention for the Protection of Human Rights and Fundamental Freedoms, ETS, No. 117, par. 13.2.

9 Ibidem, par. 14.

10 Ibidem, par. 16.

11 Orzeczenie ETPC z 5 października 2000 r., Maaouia p. Francji, skarga nr 39652/98.
} 
ma tu zastosowania ${ }^{12}$. Argumentacja Trybunału opierała się na założeniu, że przez przyjęcie art. 1 Protokołu nr 7, który określa gwarancje proceduralne w zakresie wydalania obcokrajowców, państwa strony Konwencji wyraźnie wskazały swój zamiar wyłączenia procedury wydalenia spod zakresu przedmiotowego art. 6 ust. $1^{13}$. Ze sposobu sformułowania art. 1 Protokołu nr 7 expressis verbis wynika, że chodzi o gwarancje procesowe $\mathrm{w}$ postępowaniu administracyjnym ${ }^{14}$. Tym samym przepis ten nie nawiązuje do sądowej procedury, która jest przedmiotem art. 6 EKPC.

Należy podkreślić, że podejście Trybunału wyrażone w orzeczeniu Maaouia p. Francji spotkało się z krytyką ze strony części przedstawicieli doktryny ${ }^{15}$. Uważam jednak, że krytyce należałoby poddać nie stanowisko ETPC, ale regulację art. 1 Protokołu $\mathrm{nr} 7$, gdyż to ona daje cudzoziemcom ograniczone gwarancje skorzystania z właściwej procedury prawnej. Wskazówek co do powyższej interpretacji art. 1 Protokołu nr 7 dostarcza Trybunałowi Komentarz wyjaśniający, wyrażający oficjalne stanowisko jego autorów, z którego jednoznacznie wynika, że przepis ten został dodany do Konwencji po to, by zapewnić cudzoziemcom „minimalne” gwarancje proceduralne w wypadku wydalenia $\mathrm{z}$ terytorium państwa strony ${ }^{16} \mathrm{i}$ nie wpływa na przyjętą interpretację art. $6 \mathrm{EKPC}^{17}$.

Warto zauważyć, że Trybunał kilkakrotnie zwracał uwagę, iż osoba w stosunku do której zastosowano wydalenie ze względu na ochronę bezpieczeństwa państwa, musi mieć możliwość przeprowadzenia postępowania przed niezależnym i bezstronnym organem, kompetentnym do ustalenia wszystkich istotnych okoliczności faktycznych oraz przepisów prawa w celu stwierdzenia legalności zastosowanego środka $\mathrm{w}$ postaci wydalenia. Przed takim organem cudzoziemiec musi mieć zapewniony udział w postępowaniu kontradyktoryjnym, w którym może przedstawić swój punkt widzenia i zakwestionować argumenty władz ${ }^{18}$. Tym samym Trybunał odwołuje się do zasad rzetelnego procesu $\mathrm{w}$ sprawach dotyczących wydalania cudzoziemców $\mathrm{z}$ kraju legalnego pobytu.

12 Ibidem, par. 40-41.

13 Ibidem, par. 36-37.

${ }^{14}$ N. Sitaropoulos, The Role and Limits of the European Court of Human Rights in Supervising State Security and Anti-Terrorism Measures Affecting Aliens' Right, w: E. Guild, A. Baldaccini, Terrorism and the Foreigner: A Decade of Tension around the Rule of Law in Europe, Martinus Nijhoff Publishers, The Hague 2007, s. 102. W przeciwieństwie do art. 6, art. 1 Protokołu nr 7 nie zawiera żadnych konkretnych wymogów odnośnie do zakresu i sposobu ponownego rozpatrzenia sprawy, w szczególności jeśli chodzi o zasadę bezstronności sądów, zasadę równości broni, prawo do korzystania z kontradyktoryjnych procedur w celu przedstawienia swojego punktu widzenia czy prawo do przesłuchania.

${ }^{15}$ H. Lambert, The Position of Aliens in Relation to the European Convention on Human Rights, Council of Europe Publishing, 2007, s. 24; N. Sitaropoulos, op. cit., s. 100-102. Również dwóch sędziów Trybunału - L. Loucaides i K. Traja - w swoim zdaniu odrębnym skrytykowało Trybunał za jego niechęć do nadania bardziej liberalnej interpretacji pojęciu praw i obowiązków o charakterze cywilnoprawnym.

${ }^{16}$ Explanatory Report on Protocol No. 7 to the Convention for the Protection of Human Rights and Fundamental Freedoms, ETS, No. 117, par. 7.

17 Ibidem, par. 16.

18 Orzeczenie ETPC z 8 czerwca 2006 r., Lupsa p. Rumunii, skarga nr 10337/04, par. 38; Orzeczenie ETPC z 20 czerwca 2002 r., Al-Nashif p. Butgarii, skarga nr 50963/99, par. 123. Zob. także: R. White, C. Ovey, The European Convention on Human Rights, wyd. 5, Oxford University Press, Oxford 2010, s. 545 . 
Na ograniczony charakter gwarancji przeciw wydaleniu zwróciło także uwagę Zgromadzenie Parlamentarne Rady Europy: wydało zalecenia państwom członkowskim w przedmiocie niewydalania imigrantów długoterminowych. Na podstawie tych zaleceń cudzoziemiec powinien mieć zagwarantowane prawo dostępu do sędziego, prawo do procesu sądowego, prawo do pomocy ze strony adwokata oraz prawo do wniesienia środka odwoławczego ze skutkiem zawieszającym $\mathrm{z}$ uwagi na nieodwracalne konsekwencje związane $\mathrm{z}$ wykonaniem decyzji o wydaleniu ${ }^{19}$.

\section{PRAWO DO SKUTECZNEGO ŚRODKA ODWOKAWCZEGO NA PODSTAWIE ART. 13 KONWENCJI O OCHRONIE PRAW CZŁOWIEKA I PODSTAWOWYCH WOLNOŚCI}

Analizując dotychczasowy dorobek orzeczniczy Europejskiego Trybunału Praw Człowieka (ETPC), można dojść do wniosku że, art. 1 Protokołu nr 7 nie odegrał jak dotąd znaczącej roli $\mathrm{w}$ praktyce ${ }^{20}$. Na taki stan rzeczy składają się trzy zasadnicze powody. Po pierwsze, przysługujące cudzoziemcom gwarancje proceduralne $\mathrm{w}$ procesie wydalenia pozostaja poza zakresem prawa do rzetelnego procesu sądowego na podstawie art. 6 EKPC. Po drugie, niektóre państwa w dalszym ciagu odmawiaja ratyfikacji Protokołu nr 7. Po trzecie, zaistniałą lukę $\mathrm{w}$ zapewnieniu cudzoziemcom proceduralnej ochrony przed wydaleniem stara się wypełnić art. 13 EKPC, który formułuje prawo do skutecznego środka odwoławczego ${ }^{21}$. Zgodnie z tym przepisem: „Każdy, kogo prawa i wolności zawarte $\mathrm{w}$ niniejszej Konwencji zostały naruszone, ma prawo do skutecznego środka odwoławczego do właściwego organu państwowego także wówczas, gdy naruszenia dokonały osoby wykonujące swoje funkcje urzędowe" 22 .

Trybunał wielokrotnie wyjaśniał, że w wypadku wydalenia cudzoziemców przebywających legalnie na terytorium państwa moga oni korzystać, oprócz art. 1 Protokołu nr 7, z ochrony przyznanej im przez art. 3, 8 łącznie z art. 13 EKPC. Tym samym zawarte $\mathrm{w}$ tych właśnie przepisach gwarancje proceduralne i środki odwoławcze (remedies) pokrywają się częściowo z ochroną przyznaną przez art. 1 Protokołu $\mathrm{nr} 7 \mathrm{i}$ w pewnym zakresie rekompensują brak stosowania art. 6 EKPC do spraw dotyczących ,wjazdu, pobytu i wydalenia” cudzoziemców. Wszystko to sprawia, że zarzut naruszenia art. 1 Protokołu nr 7 pojawia się

\footnotetext{
${ }^{19}$ Parliamentary Assembly of the Council of Europe, Recommendation 1504(2001): Non-expulsion of long-term immigrants, z 14 marca 2001 r., par. 11j. Zob. także: Parliamentary Assembly of the Council of Europe, Recommendation 1624(2003): Common policy on migration and asylum, z 30 września 2003 r., par. 9.

${ }^{20}$ Naruszenie art. 1 Protokołu nr 7 EKPC zostało uznane przez Trybunał w następujących sprawach: orzeczenie ETPC z 8 czerwca 2006 r., Lupsa p. Rumunii, skarga nr 10337/04; orzeczenie ETPC z 5 października 2006 r., Bolat p. Rosji, skarga nr 14139/03; orzeczenie ETPC z 24 kwietnia 2008 r., C.G. $i$ inni p. Butgarii, skarga nr 1365/07; orzeczenie ETPC z 12 lutego 2009, Nolan $i$ K. p. Rosji, skarga nr 2512/04.

${ }^{21}$ H. Lambert, op. cit., s. 36; P. Boeles et al., European Migration Law, Antwerp-Oxford-Portland, 2009, s. 381.

${ }^{22}$ Dz. U. 1993, Nr 61, poz. 284.
} 
najczęśsiej jako subsydiarny lub uzupełniający w stosunku do zarzutu naruszenia powyższych przepisów Konwencji ${ }^{23}$.

Artykuł 13 gwarantuje efektywną ochronę praw i wolności określonych w EKPC na szczeblu krajowym. Zdaniem Trybunału wyraża on ,bezpośrednie zobowiązanie państwa-strony Konwencji do ochrony praw człowieka, w pierwszej kolejności i nade wszystko wewnątrz własnego systemu prawnego" ${ }^{24}$. Celem tej regulacji jest mianowicie ,zapewnienie środka, na mocy którego osoby mogą uzyskać zadośćuczynienie, na poziomie krajowym, za naruszenie ich praw konwencyjnych, zanim wprawią w ruch międzynarodowy instrument skarg do Trybunału" ${ }^{25}$.

Należy wskazać, że art. 13 EKPC nie ma samoistnego znaczenia prawnego i może być stosowany tylko w powiązaniu z prawami i wolnościami wymienionymi w Konwencji lub poszczególnych protokołach. Charakter akcesoryjny tego przepisu polega bowiem na tym, że ma on zastosowanie tylko wówczas, gdy jednocześnie naruszone zostały prawa lub wolności, a naruszenie to można zakwestionować na gruncie EKPC. Innymi słowy, zarzut naruszenia art. 13 musi zawsze pojawiać się $\mathrm{w}$ związku z zarzutem naruszenia jednego $\mathrm{z}$ innych materialnych postanowień Konwencji ${ }^{26}$. Według Trybunału przepis ten „,musi być rozumiany, jako zapewniający skuteczny środek odwoławczy do właściwego organu państwowego każdemu, kto twierdzi, że naruszone zostały jego prawa i wolności chronione przez Konwencję" ${ }^{27}$. W związku z tym cudzoziemiec może skarżyć naruszenie prawa do efektywnego środka odwoławczego od decyzji o wydaleniu tylko wtedy, gdy jego zdaniem decyzja o wydaleniu narusza zarazem prawa określone w Konwencji, a zwłaszcza art. 3 lub $8 \mathrm{EKPC}^{28}$.

\section{POJECIE UZASADNIONEGO ROSZCZENIA (ARGUABLE CLAIM)}

Jak wynika z bogatego dorobku orzeczniczego Trybunału, art. 13 Konwencji wymaga zapewnienia w prawie krajowym skutecznego środka odwoławczego:

a) gdy jednostka ma dające się uzasadnić roszczenie (arguable claim) z tego tytułu, że jest ofiarą naruszenia praw gwarantowanych przez Konwencję;

b) przez możliwość rozpoznania sprawy przez organ, który niekoniecznie musi być organem sądowym. Jeśli jednak nie jest, to w takim wypadku zawsze

${ }^{23}$ A. Wróbel, Protokót nr 7 do Konwencji o ochronie praw człowieka $i$ podstawowych wolności, w: L. Garlicki (red.), Konwencja o ochronie praw człowieka i podstawowych wolności, t. 2: Komentarz do artykutów 19-59 oraz do protokołów dodatkowych, C. H. Beck, Warszawa 2011, s. 621; P. Boeles, Fair Immigration Proceedings in Europe, Martinus Nijhoff Publishers, The Hague 1997, s. 224.

${ }^{24}$ Orzeczenie ETPC z 26 października 2000 r., Kudta p. Polsce, skarga nr 30210/96, par. 152.

${ }^{25}$ Ibidem.

${ }^{26}$ P. Hofmański, A. Wróbel, Prawo do skutecznego środka odwotawczego, w: Konwencja o ochronie praw człowieka i podstawowych wolności, t. 1: Komentarz do art. 1-18, C. H. Beck, Warszawa 2010, s. 725.

${ }^{27}$ Orzeczenie ETPC z 6 września 1978 r., Klass $i$ inni p. Republice Federalnej Niemiec, skarga nr 5029/71, par. 64 .

${ }^{28}$ A. Wróbel, Protokót $n r 7$ do Konwencji..., s. 625. Zob. także: A. Szklanna, Ochrona prawna cudzoziemca $w$ świetle orzecznictwa Europejskiego Trybunału Praw Człowieka, Instytut Wydawniczy EuroPrawo, Warszawa 2010, s. 200; H. Lambert, op. cit., s. 36. 
wnikliwie ocenia się, czy kompetencje i gwarancje oferowane przez organ pozasądowy są dostateczne do zapewnienia ,,skuteczności” takiego środka odwoławczego;

c) za pośrednictwem różnych metod zadośćuczynienia lub podjęcia innych środków naprawczych (redress) ${ }^{29}$.

Artykuł 13 EKPC gwarantuje zatem dostępność na poziomie krajowym skutecznego środka odwoławczego celem ochrony - tj. urzeczywistniania, wyegzekwowania - istoty praw i wolności ustanowionych w Konwencji, niezależnie od tego, w jakiej formie środek ten zostanie zapewniony w krajowym porządku prawnym ${ }^{30}$.

$\mathrm{Na}$ podstawie art. 13 EKPC cudzoziemiec dochodzący praw i wolności przewidzianych w Konwencji powinien mieć do dyspozycji środek prawny, dzięki któremu jego sprawa będzie rozpatrzona przez władzę krajową lub zostanie naprawiona szkoda wynikła $\mathrm{z}$ naruszenia jego praw lub wolności. Oznacza to, jak słusznie zwracają uwage P. Hofmański i A. Wróbel, że zmieszczone określenie ,środek odwoławczy” należy rozumieć szeroko, ,jako każdy środek prawny, który umożliwia rozpatrzenie sprawy np. roszczenie, podnoszenie w toku postępowania zarzutów naruszenia Konwencji, właściwe środki odwoławcze, jak prawo apelacji czy kasacji, a także wszelkiego rodzaju roszczenia kompensacyjne, odszkodowawcze czy restytucyjne" ${ }^{31}$.

Trybunał zrezygnował ze sformułowania abstrakcyjnej definicji pojęcia „uzasadnialność” (arguability) ${ }^{32}$, uznając, że „,należy raczej określić w świetle szczegółowych okoliczności faktycznych i istoty kwestii prawnych, czy każdy indywidualny zarzut naruszenia tworzący podstawę skargi dawał się uzasadnić na podstawie art. 13, a jeżeli tak, to czy zostały spełnione wymogi art. 13 w odniesieniu do tego zarzutu" ${ }^{33}$. W rezultacie tego Trybunał precyzuje pojęcie „uzasadnialne roszczenie” przez pryzmat konkretnych okoliczności każdej sprawy. Im silniejsze są więc prawne i dowodowe elementy roszczenia, tym większe jest prawdopodobieństwo, że spełni ono kryteria ,uzasadnialnego roszczenia".

${ }^{29}$ Orzeczenie ETPC z 25 marca 1983 r., Silver $i$ inni p. Wielkiej Brytanii, skargi nr 5947/72, 6205/73, 7052/75, 7107/75, 7113/75, 7136/75, par. 113; zob. także: orzeczenie ETPC Klass $i$ inni p. Republice Federalnej Niemiec, skarga nr 5029/71, par. 67; orzeczenie ETPC z 26 marca 1987 r., Leander p. Szwecji, skarga nr 9248/81, par. 77, 84; A. R. Mowbray, The Development of Positive Obligations under the European Convention on Human Rights by the European Court of Human Rights, Oxford-Portland-Oregon 2004, s. 206-207.

${ }^{30}$ Orzeczenie ETPC z 4 maja 2000 r., Rotaru p. Rumunii, skarga nr 28341/95, par. 67. Należy zauważyć, że państwa strony Konwencji mają zapewnioną pewną dyskrecję co do sposobu, w jaki zapewniają zadośćuczynienie wymagane przez art. 13 i dostosowują się do swoich zobowiązań konwencyjnych na podstawie tego artykułu, orzeczenie ETPC, Kudta p. Polsce, par. 154. Z kolei we wcześniejszej sprawie Smith $i$ Grady p. Wielkiej Brytanii Trybunał uznał, że państwom stronom Konwencji przysługuje margines oceny w dostosowaniu się do obowiązków określonych w tym przepisie, orzeczenie ETPC z 27 września 1999 r., skarga nr 33985/96, skarga nr 33986/96, par. 135.

${ }^{31}$ P. Hofmański, A. Wróbel, op. cit., s. 728. Ponadto autorzy ci podkreślają, że o szerokim rozumieniu pojęcia ,,́́rodek odwoławczy” świadczy również to, że czasami Trybunał posługuje się innym terminem, tj. relief, którego używa się do ogólnego określenia środków zapewniających naprawienie (zadośćuczynienie) naruszenia praw i wolności chronionych przez Konwencję.

${ }^{32}$ Polskie tłumaczenie podaję za: P. Hofmański, A. Wróbel, op. cit., s. 735.

${ }^{33}$ Orzeczenie ETPC z 27 kwietnia 1988 r., Boyle i Rice p. Wielkiej Brytanii, skarga nr 9659/82, skarga nr 9658/82, par. 55 . 
Warto zauważyć, że w wielu sprawach, w których cudzoziemcy powoływali się na naruszenie art. 3 Konwencji i jednocześnie art. 13, Trybunał odrzucał zarzut naruszenia tego drugiego, jeżeli uznał, iż zarzut dotyczący tego pierwszego przepisu był w sposób oczywisty nieuzasadniony. Taka sytuacja miała miejsce np. w sprawie Conka $p$. Belgii, w której Trybunał nie dopatrzył się naruszenia art. $13 \mathrm{w}$ powiązaniu $\mathrm{z}$ art. 3 Konwencji, lecz stwierdził naruszenie tego pierwszego przepisu $\mathrm{w}$ powiązaniu $\mathrm{z}$ art. 4 Protokołu dodatkowego $\mathrm{nr} 4$ do $\mathrm{EKPC}^{34}$.

\section{SKUTECZNOŚĆ ŚRODKA ODWOŁAWCZEGO}

Trybunał stoi na stanowisku, że środek odwoławczy wymagany przez art. 13 EKPC musi być ,,skuteczny” zarówno w praktyce, jak i w prawie ${ }^{35}$. Skuteczność środka odwoławczego wyraża się w tym, że może „,zapobiec ewentualnemu naruszeniu lub jego kontynuacji, lub zapewnić adekwatne naprawienie jakiegokolwiek naruszenia, które miało już miejsce" ${ }^{36}$. W orzecznictwie strasburskim przyjmuje się, że krajowy środek odwoławczy spełnia wymagania skuteczności, pod warunkiem że odpowiada przesłankom:

- adekwatności: środek ten musi umożliwiać rozpatrzenie przez właściwy organ krajowy istoty skargi;

- efektywności: środek ten musi umożliwiać zapewnienie odpowiedniego naprawienia naruszenia przez przyznanie zadośćuczynienia ${ }^{37}$.

Aby środek odwoławczy był skuteczny, musi być dostępny dla skarżącego oraz gwarantować rozpoznanie zarzutu naruszenia praw (wolności) chronionych EKPC w ramach sprawiedliwej procedury. Oczywiście zakwalifikowanie danego środka jako skutecznego na podstawie art. 13 EKPC nie oznacza pozytywnego rozstrzygnięcia dla skarżącego ${ }^{38}$.

W sprawie Chahal p. Wielkiej Brytanii Trybunał stwierdził, że środek odwoławczy, którym dysponował skarżący przeciwko naruszeniu art. 3 Konwencji, nie był adekwatny $\mathrm{z}$ powodu ograniczenia $\mathrm{w}$ jego stosowaniu $\mathrm{w}$ związku z ochroną bezpieczeństwa państwa ${ }^{39}$. Skarżący złożył wniosek o azyl polityczny, uzasadniając, że w razie deportacji do Indii będzie narażony na tortury. Wniosek ten został oddalony, w wyniku czego skarżący zamierzał wnieść odwołanie od decyzji ministra spraw wewnętrznych o jego deportacji do sądu. $\mathrm{W}$ tej sprawie sąd nie mógł jednakże rozpatrywać odwołania co do istoty i ograniczył się jedynie do kwestii proceduralnych. Minister powołał się bowiem na argument ochrony bezpieczeństwa państwa w celu uzasadnienia swojej decyzji o wydaleniu skarżącego, co skutkowało tym, że sędziowie nie mieli

${ }^{34}$ Orzeczenie ETPC z 5 lutego 2002 r., Conka p. Belgii, skarga nr 51564/99, par. 81-83.

${ }^{35}$ Orzeczenie ETPC z 26 października 2000 r., Kudta p. Polsce, skarga nr 30210/96, par. 157.

${ }^{36}$ Ibidem, par. 158.

${ }^{37}$ P. Hofmański, A. Wróbel, op. cit., s. 727.

${ }^{38}$ P. Boeles, Fair Immigration..., s. 272; zob. także: orzeczenie ETPC z 30 października 1991 r., Vilvarajah i inni p. Wielkiej Brytanii, skargi nr 13163/87; 13164/87; 13165/87; 13447/87; 13448/87, par. 122; orzeczenie ETPC z 20 czerwca 2002 r., Al-Nashif p. Butgarii, skarga nr 50963/99, par. 132.

${ }^{39}$ Orzeczenie ETPC z 15 listopada 1996 r., Chahal p. Wielkiej Brytanii, skarga nr 22414/93. 
uprawnień do jej podważenia, w szczególności do zbadania dowodów, na których oparł on swoje stwierdzenie. Wobec powyższego Trybunał uznał, że środek odwoławczy, którym skarżący dysponował w prawie angielskim, nie spełniał wymogów z art. 13 Konwencji (naruszenie art. 13 wraz z art. 3 Konwencji). Zdaniem Trybunału nie można było zaakceptować sytuacji, w której względy bezpieczeństwa państwa uniemożliwiałyby zbadanie zarzutu, że skarżący byłby narażony na ryzyko nieludzkiego traktowania po jego wydaleniu z Wielkiej Brytanii ${ }^{40}$.

Z kolei w sprawie Al-Nashif p. Butgarii Trybunał stwierdził, że art. 13 w połączeniu z art. 8 Konwencji wymaga od państw zapewnienia, aby jednostka miała rzeczywista możliwość kwestionowania nakazu deportacji lub odmowy zgody na pobyt oraz żeby jej sprawa została szczegółowo zbadana przez organ oferujący odpowiednie gwarancje niezależności i bezstronności ${ }^{41}$. Sąd bułgarski odrzucił odwołanie skarżącego, powołując się na ustawę o cudzoziemcach, zgodnie z którą minister spraw wewnętrznych jest uprawniony do wydania nakazu deportacji bez żadnego postępowania kontradyktoryjnego, bez uzasadnienia i bez możliwości odwołania się do niezależnego organu. Na marginesie warto zauważyć, że skarżący nie mógł skorzystać z gwarancji proceduralnych $\mathrm{z}$ art. 1 Protokołu $\mathrm{nr} 7$, gdyż w owym czasie nie wiązał on tego państwa. Trybunał wyraził pogląd, że w sprawach wydalania cudzoziemców ze względu na bezpieczeństwo państwa gwarancje skutecznego środka odwoławczego wymagaja przynajmniej tego, aby właściwy niezależny organ odwoławczy został poinformowany o powodach decyzji o deportacji, nawet jeśli nie sa one publicznie dostępne. $\mathrm{W}$ tym wypadku cudzoziemcowi nie zapewniono takiego środka. Nastąpiło więc naruszenie art. 13 Konwencji.

Także w innych sprawach Trybunał negatywnie ocenił istniejące w prawie krajowym środki odwoławcze od decyzji o wydaleniu w kontekście art. 8 Konwencji. W sprawie C.G. $i$ inni p. Butgarii stwierdził, że kontrola sprawowana przez sądy krajowe była niewłaściwa, gdyż nie zbadały one, czy decyzja o wydaleniu skarżącego została podjęta rzeczywiście na podstawie klauzuli bezpieczeństwa państwa, ani nie zweryfikowały twierdzeń organu wykonawczego, czy skarżący stwarzał zagrożenie $\mathrm{w}$ tej materii ${ }^{42}$. Władze nie tylko nie udzieliły skarżącemu żadnych wyjaśnień co do faktów, na podstawie których powzięły takie przekonanie, lecz także nie zagwarantowały mu uczciwej możliwości ich zakwestionowania. Ponadto Trybunał zauważył, że sądy krajowe nie dokonały oceny proporcjonalności nakazu wydalenia $\mathrm{w}$ stosunku do celu, któremu miało ono służyć - ochronie bezpieczeństwa państwa ${ }^{43}$. Trybunał uznał, że w tym wypadku nie zapewniono skarżącym skutecznego środka odwoławczego w rozumieniu art. 13 Konwencji, ponieważ procedura kontroli sądowej nie była równoznaczna z możliwością, dzięki której skarżący mogliby należycie dowieść słuszności swojego prawa do poszanowania życia rodzinnego ${ }^{44}$.

\footnotetext{
40 Ibidem, par. 150-151.

${ }^{41}$ Orzeczenie ETPC z 20 czerwca 2000 r., Al-Nashif p. Butgarii, skarga nr 50963/99, par. 133.

${ }^{42}$ Orzeczenie ETPC z 24 kwietnia 2008 r., C.G. $i$ inni p. Butgarii, skarga nr 1365/07, par. 60.

43 Ibidem, par. 61.

44 Ibidem, par. 63.
} 
W sytuacji zagrożenia wydaleniem środek odwoławczy z art. 13 EKPC jest skuteczny, jeśli pozwala na zawieszenie wykonania decyzji o deportacji cudzoziemca. H. Lambert podkreśla, że w kontekście odwołania się cudzoziemca od decyzji o wydaleniu ze względu na możliwość naruszenia art. 3 EKPC, środek odwoławczy musi mieć charakter zawieszający ${ }^{45}$. Jeśli cudzoziemcowi grozi ryzyko tortur lub nieludzkiego traktowania $\mathrm{w}$ państwie, do którego ma zostać wydalony, to z przepisu art. 13 Konwencji wynika konieczność zapewnienia mu możliwości wniesienia odwołania wstrzymującego $\mathrm{z}$ mocy prawa wykonanie zaskarżonej decyzji ${ }^{46}$. Gdyby tak nie było, ochrona prawna na podstawie EKPC (np. art. 3) byłaby bezprzedmiotowa, dlatego że następowałaby dopiero po wykonaniu decyzji o wydaleniu cudzoziemca ${ }^{47}$. Ponadto Komisarz Rady Europy ds. Praw Człowieka, wydając zalecenia państwom członkowskim, zwrócił uwagę, iż ,niezbędnym jest, aby prawo do skutecznego środka odwoławczego w rozumieniu art. 13 Konwencji było nie tylko zagwarantowane przez prawo, ale przyznane w praktyce, gdy jednostka twierdzi, że właściwe władze naruszyły albo jest wysoce prawdopodobnym, że naruszą prawo przewidziane Konwencją. Prawo do skutecznego środka odwoławczego musi być zapewnione każdemu, kto domaga się zakwestionowania nakazu wydalenia lub refoulement" ${ }^{48}$.

\section{PRAWO CUDZOZIEMCA \\ DO WNIESIENIA ŚRODKA ODWOŁAWCZEGO \\ W PROCEDURZE WYDALENIOWEJ NA PODSTAWIE POLSKICH PRZEPISÓW}

Decyzja o wydaleniu cudzoziemca z terytorium Rzeczypospolitej Polskiej wydawana jest $\mathrm{w}$ postępowaniu administracyjnym $\mathrm{z}$ zachowaniem szeregu gwarancji procesowych i środków jej kontroli na drodze administracyjnej oraz sądowej ${ }^{49}$. Tryb postępowania jest zróżnicowany w zależności od charakteru przesłanek wydalenia i pilności jego wykonania ze względu na chronione interesy publiczne. Cudzoziemiec na podstawie art. 129 ust. 1 i ust. 2 k.p.a. ma prawo złożyć odwołanie od decyzji o wydaleniu do szefa Urzędu do spraw Cudzoziemców za pośrednictwem wojewody, który wydał decyzję, w terminie czternastu dni od dnia jej doręczenia. Złożenie odwołania powoduje wstrzymanie wykonania decyzji (art. 130 ust. 2 k.p.a.). Natomiast nie powoduje wstrzymania wykonania decyzji odwołanie od decyzji, której nadano rygor

${ }^{45}$ H. Lambert, op. cit., s. 38.

${ }^{46}$ Orzeczenie ETPC z 26 kwietnia 2007 r., Gebremedhin p. Francji, skarga nr 25389/05, par. 66.

${ }^{47}$ A. Szklanna, op. cit., s. 203.

${ }^{48}$ Recommendation of the Council of Europe Commissioner for Human Rights concerning the rights of aliens wishing to enter a Council of Europe member State and the enforcement of expulsion orders, CommDH/Rec(2001)1, z 19 września 2001 r., par. 11.

49 J. Borkowski, w: J. Chlebny (red.), Prawo o cudzoziemcach. Komentarz, C. H. Beck, Warszawa 2006, s. 205. 
natychmiastowej wykonalności ${ }^{50}$. Nadanie rygoru natychmiastowej wykonalności powoduje, że decyzja podlega wykonaniu z chwila jej doręczenia cudzoziemcowi, pomimo możliwości złożenia od niej odwołania. Należy jednak zauważyć, że nadanie rygoru natychmiastowej wykonalności nie ma charakteru bezwzględnego i podlega ono kontroli organu wyższego stopnia, który w uzasadnionych wypadkach zgodnie $\mathrm{z}$ art. 135 k.p.a. może wstrzymać natychmiastowe wykonanie decyzji, gdy stwierdzi brak podstaw do nadania takiego rygoru. Decyzji o wydaleniu nadaje się rygor natychmiastowej wykonalności, jeśli pobyt cudzoziemca na terytorium Rzeczypospolitej Polskiej zagraża obronności lub bezpieczeństwu państwa, lub ochronie bezpieczeństwa i porządku publicznego albo naruszałby interes Rzeczypospolitej Polskiej ${ }^{51}$.

Ocena, czy istnieja przesłanki nadania decyzji o wydaleniu rygoru natychmiastowej wykonalności, należy do wojewody, który wydał decyzję. Jeżeli stwierdzi on, że istnieją przesłanki określone w art. 90. ust. 2 ustawy o cudzoziemcach, to obowiązany jest nadać decyzji rygor natychmiastowej wykonalności, który wymaga uzasadnienia w decyzji ${ }^{52}$. Naczelny Sąd Administracyjny podkreślił, że przesłanki uzasadniające taki rygor muszą być poddane ścisłej wykładni ${ }^{53}$. W doktrynie przyjmuje się, że chodzi o zagrożenie potencjalne, co stanowi przedmiot oszacowania przez organ wydający decyzję, mając na względzie własne dane służące ocenie sytuacji albo dane wniosku o wydalenie cudzoziemca podmiotów wymienionych w art. 92 ust. 1 ustawy oraz wyniki postępowania wyjaśniającego $\mathrm{w}$ tej sprawie ${ }^{54}$. Należy zauważyć, że wojewoda może nadać decyzji rygor natychmiastowej wykonalności, ale nie jest do tego zobowiązany, zależy to od jego uznania ${ }^{55}$. Skorzystanie przez organ lub nieskorzystanie $\mathrm{z}$ tego uznania musi być następstwem wszechstronnego rozważenia przezeń okoliczności sprawy $\mathrm{w}$ istotnym dla rozstrzygnięcia zakresie $^{56}$. Należy podkreślić, że „uznanie administracyjne oznacza, iż skoro decyzja podejmowana jest na podstawie tzw. uznania administracyjnego, to wydaniu decyzji powinno towarzyszyć pełne przekonanie organu administracyjnego o słuszności rozstrzygnięcia, co może nastąpić jedynie w wypadku zgromadzenia niebudzącego żadnych wątpliwości materiału dowodowego" ${ }^{57}$. W sprawach dotyczących cudzoziemców Naczelny Sąd Administracyjny ,,wielokrotnie dawał wyraz konieczności takiego przygotowania uzasadnienia decyzji uznaniowych, aby dały się bez wszelkich wątpliwości skontrolować, przekonując nie tylko organ administracji, lecz także kontrolujący sąd o trafności rozstrzygnięcia, a sposobem prowadzenia postępowania umacniały zaufanie

${ }^{50}$ Zob. art. 108 i 130 ust. 3 k.p.a. Przyjmuje się, że art. 108 k.p.a. przewiduje wyjątek od zasady niewykonywania decyzji nieostatecznych.

${ }_{51}$ Art. 90 ust. 2 ustawy z 13 czerwca 2003 r. o cudzoziemcach, Dz. U. 2006, Nr 234, poz. 1694.

52 Zob. wyrok NSA z 15 lipca 2010 r., II OSK 1134/09.

${ }^{53}$ Wyrok NSA z 30 czerwca 2006 r., I OSK 116/06.

54 J. Borkowski, op. cit., s. 216.

${ }_{55}$ J. Białocerkiewicz, Nowe polskie prawo o cudzoziemcach, TNOiK „Dom Organizatora”, Toruń 2003, s. 70 .

${ }^{56}$ Wyrok WSA w Bydgoszczy z 25 lipca 2012 r., II SA/Bd 468/12.

${ }^{57}$ Wyrok NSA z 3 sierpnia 1999 r., V SA 230/99. 
zainteresowanego do rzetelności działania polskich organów władzy publicznej" 58 .

Z kolei od decyzji szefa Urzędu przysługuje cudzoziemcowi skarga do wojewódzkiego sądu administracyjnego. Jeśli wojewódzki sąd administracyjny nie uchyli decyzji o wydaleniu, cudzoziemiec może się odwołać - wnieść skargę kasacyjna - do Naczelnego Sądu Administracyjnego. W sytuacji gdy wojewódzki sąd administracyjny nie wyda wyroku przed terminem określonym $\mathrm{w}$ decyzji o wydaleniu, cudzoziemiec powinien opuścić terytorium Polski i - przebywając za granica - dochodzić swych praw przed polskim sądem. W tym celu może wyznaczyć pełnomocnika, który będzie go reprezentować. Cudzoziemiec może także skorzystać z tzw. ochrony tymczasowej w postaci złożenia do sądu wniosku o wstrzymanie wykonania zaskarżonej decyzji. Takie rozwiązanie zostało przewidziane w art. 61 ust. 3 ustawy z 30 sierpnia 2002 r. - Prawo o postępowaniu przed sądami administracyjnymi. Zgodnie z tym przepisem po przekazaniu sądowi skargi sąd może na wniosek skarżącego wydać postanowienie o wstrzymaniu wykonania w całości lub w części zaskarżonego aktu lub czynności ${ }^{59}$. Zastosowanie instytucji ochrony tymczasowej może mieć miejsce wyłącznie w wypadku zaistnienia przesłanek wymienionych w art. 61 § 3 p.p.s.a., tj. w sytuacji stwierdzenia, że zachodzi niebezpieczeństwo wyrządzenia znacznej szkody lub spowodowania trudnych do odwrócenia skutków, gdyby akt lub czynność zostały wykonane. Orzeczenie dotyczące wstrzymania wykonania zaskarżonej decyzji ma charakter fakultatywny, a zatem wydanie przedmiotowego postanowienia zależy od uznania sądu. Zaznaczyć przy tym należy, że obowiązek wykazania przesłanek uzasadniajacych wstrzymanie wykonania decyzji spoczywa na wnioskodawcy. Sąd administracyjny nie dokonuje żadnych ustaleń faktycznych w sprawie o wstrzymanie wykonania. Uwzględnione na tym etapie postępowania moga zostać tylko te argumenty, które odnoszą się do zasadności złożonego wniosku. Warto zwrócić uwagę, że Naczelny Sąd Administracyjny w postanowieniu z 31 marca 2005 r. (II OZ 155/05) stwierdził, iż: ,,wniosek o wstrzymanie wykonania zaskarżonego aktu tylko częściowo jest oparty na zasadzie skargowości. Zasada ta obowiązuje jedynie w zakresie wszczęcia postępowania w sprawie wstrzymania wykonania zaskarżonego aktu. Natomiast Sąd ma obowiązek uwzględniać z urzędu, a więc i bez wniosków strony, okoliczności decydujące o wstrzymaniu bądź odmowie wstrzymania wykonania aktu lub czynności zaskarżonych do Sądu"60.

Ponadto Naczelny Sąd Administracyjny wyraził pogląd, że ,wyjazd skarżącego z Polski przed rozpoznaniem sprawy przez Wojewódzki Sąd Administracyjny w Warszawie pozbawi go nie tylko możliwości osobistego uczestnictwa $\mathrm{w}$ postępowaniu sądowym, a tym samym skorzystania $\mathrm{w}$ pełnym zakresie z prawa do sądu, lecz także sprawi, że w razie ewentualnego uwzględnienia skargi, udzielona cudzoziemcowi ochrona sądowa może okazać się iluzoryczna" ${ }^{\prime 1}$.

\footnotetext{
58 Ibidem.

59 Dz. U. 2002, Nr 153, poz. 1270 (dalej jako: p.p.s.a.).

${ }^{60}$ Postanowienie NSA z 31 marca 2005 r., II OZ 155/05.

${ }^{61}$ Wyrok NSA z 14 grudnia 2005 r., II OZ 1330/05.
} 
Orzecznictwo sądów administracyjnych wskazuje zatem wyraźnie, że wstrzymanie wykonania decyzji o wydaleniu do czasu zakończenia postępowania sądowoadministracyjnego $\mathrm{w}$ sprawie decyzji w przedmiocie wydalenia z terytorium Rzeczypospolitej Polskiej jest nieodłącznym warunkiem zachowania standardów rzetelnej procedury i realizacji prawa do sądu ${ }^{62}$.

\section{WNIOSKI}

Podsumowując, należy uznać art. 13 EKPC za jeden z kluczowych przepisów gwarantujących proceduralną ochronę cudzoziemca przed wydaleniem, mimo że ma zastosowanie tylko wówczas, gdy jednocześnie naruszone zostały prawa lub wolności skarżącego określone w Konwencji. Zakres zastosowania przepisów materialnoprawnych (np. art. 3, art. 8 Konwencji) i art. 13 Konwencji w odniesieniu do cudzoziemców jest bez wątpienia znacznie szerszy niż samego tylko środka odwoławczego na podstawie art. 1 Protokołu nr 7. Wymaga podkreślenia, że efektywność omawianego uprawnienia zależy przede wszystkim od tego, czy odwołanie ma efekt suspensywny, który powodowałby wstrzymanie wykonania decyzji o wydaleniu w momencie złożenia odwołania.

W Polsce decyzje $\mathrm{w}$ przedmiocie wydalenia podlegaja sądowoadministracyjnej kontroli z punktu widzenia ich zgodności z prawem. Nie ulega wątpliwości, że przewidziana przez polskiego ustawodawcę możliwość zawieszania decyzji o wydaleniu ma ogromne znaczenie dla ochrony cudzoziemców przed arbitralnym wydaleniem. Aby jednak cudzoziemiec miał szansę skorzystania z tego uprawnienia, musi on mieć fizyczną możliwość złożenia skargi do wojewódzkiego sądu administracyjnego oraz przebywania na terytorium RP do czasu wstrzymania przez sąd wykonania decyzji o wydaleniu.

dr Julia Wojnowska-Radzińska

yuliaa@op.pl

${ }^{62}$ Wyrok NSA z 14 grudnia 2005 r., II OZ 1330/05; zob. także: postanowienie WSA w Warszawie z 9 września 2009 r., V SA/Wa 831/09; postanowienie WSA w Warszawie z 11 czerwca 2011 r., V SA/Wa $62 / 11$. 


\section{AN ALIEN'S RIGHT TO APPEAL IN AN EXPULSION PROCEDURE IN LIGHT OF THE CONVENTION FOR THE PROTECTION OF HUMAN RIGHTS AND FUNDAMENTAL FREEDOMS}

\section{Summary}

In cases concerning expulsion of aliens, an expulsion decision should identify a competent authority as well as applicable provisions of substantive law and relevant procedural rules. An alien should be granted a right to appeal to an independent authority requesting revision of the legality of the expulsion order. The effectiveness of the above right depends on whether it has a suspensive effect leading to a State suspending an expulsion decision at the moment it is filed.

Under the provisions of the Convention for the Protection of Human Rights and Fundamental Freedoms (ECHR), the right of an alien to appeal against a deportation order is expressed in Article 13 and Article 1 of Protocol No. 7 to the ECHR. However, on the basis of the existing case law and decisions of the European Court of Human Rights, it may be concluded that Article 1 of Protocol No. 7 to the ECHR has not played any important role in practice. The procedural guarantees to which an alien is entitled in expulsion proceedings remain beyond the scope of the right to a fair trial under Article 6 of the ECHR. What is more, there are still countries unwilling to ratify Protocol No. 7. Thus Article 13 of the ECHR is an attempt to close the loophole concerning procedural protection against expulsion and formulates the right to an effective remedy. 
Copyright of Journal of Law, Economics and Sociology is the property of Faculty of Law and Administration of Adam Mickiewicz University in Poznan and its content may not be copied or emailed to multiple sites or posted to a listserv without the copyright holder's express written permission. However, users may print, download, or email articles for individual use.

Właścicielem praw autorskich do „Ruchu Prawniczego, Ekonomicznego i Socjologicznego” jest Wydział Prawa i Administracji Uniwersytetu im. Adama Mickiewicza w Poznaniu. Zawartość czasopisma nie może być kopiowana, przesyłana do innych stron internetowych bądź zamieszczana na blogach bez pisemnej zgody wydawcy. Niemniej artykuły można drukować, kopiować lub przesyłać w formie elektronicznej na własny użytek. 